\title{
PENGETAHUAN PEDAGANG TERHADAP TINDAKAN UPAYA PENCEGAHAN PENYAKIT COVID-19 DIPASAR KOTABATU WARKUK RANAU SELATAN
}

\section{KNOWLEDGE OF TRADERS ON MEASURES TO PREVENT COVID-19 DISEASE IN KOTABATU MARKET, WARKUK RANAU SELATAN}

\author{
$\underline{\text { Toto Harto }}^{1}$, Wellys Putri Anggraini ${ }^{2}$ \\ Akademi Keperawatan Al-Ma'arif Jl. Dr Muhammad Hatta No 687 Sukaraya ${ }^{1,2}$ \\ e-mail: totoharto27@gmail.com ${ }^{1}$,wellysputri@gmail.com ${ }^{2}$
}

\begin{abstract}
ABSTRAK
Coronavirus Disease 2019 (COVID-19) adalah penyakit menular yang disebabkan oleh Severe Acute Respiratory Syndrome Coronavirus 2 (SARS-CoV-2). SARS-CoV-2 merupakan coronavirus jenis baru yang belum pernah diidentifikasi sebelumnya pada manusia. Indonesia melaporkan kasus pertama COVID-19 pada tanggal 2 Maret 2020 dan jumlahnya terus bertambah. Studi epidemiologi dan virology saat ini membuktikan bahwa COVID-19 utamanya ditularkan dari orang bergejala (simptomatik) ke orang lain yang berada jarak dekat melalui droplet. Tujuan dalam penelitian ini diketahuinya hubungan pengetahuan pedagang terhadap tindakan upaya pencegahan penyakit COVID-19 dipasar Kotabatu Warkuk Ranau Selatan. Jenis Penelitian ini yaitu dengan desain cross sectional. Penelitian ini dianalisis secara deskriptif dengan instrument penelitian menggunakan kuesioner. Sampel dalam penelitian ini adalah pedagang dipasar Kotabatu Warkuk Ranau Selatan yaitu sebanyak 100 orang. Hasil penelitian di simpulkan bahwa pengetahuan pedagang baik sebanyak 82 orang (82,0\%), tindakan upaya pencegahanbaik sebanyak 60 orang (60,0\%). Hasil uji statistik didapatkan p value =0,022, terdapat hubungan yang bermakna antara pengetahuan pedagang terhadap tindakan upaya pencegahan penyakit COVID-19 dipasar Kotabatu Warkuk Ranau Selatan. Diharapkan kepada pedagang di pasar kotabatu warkuk ranau selatan untuk tetap menjalankan upaya pencegahan dengan menerapkan protokol kesehatan guna untuk mencegah penyebaran COVID-19.
\end{abstract}

Kata Kunci: Pengetahuan, Pencegahan, COVID-19

\begin{abstract}
Coronavirus Disease 2019 (COVID-19) is an infectious disease caused by Severe Acute Respiratory Syndrome Coronavirus 2 (SARS-CoV-2). SARS-CoV-2 is a new type of coronavirus that has never been previously identified in humans. Indonesia reported its first case of COVID-19 on March 2, 2020 and the number continues to grow. Current epidemiological and virological studies prove that COVID-19 is mainly transmitted from symptomatic people to other people who are in close proximity through droplets. The purpose of this study was to determine the relationship between knowledge of traders and measures to prevent COVID-19 disease in the Kotabatu Warkuk Ranau Selatan market. This type of research is a cross sectional design. This research was analyzed descriptively with the research instrument using a questionnaire. The sample in this study were traders in the Kotabatu Warkuk South Ranau market, as many as 100 people. The results of the study concluded that the knowledge of traders was good as many as 82 people (82.0\%), good preventive measures as many as 60 people $(60.0 \%)$. The results of the statistical test obtained $p$ value $=0.022$, there is a significant relationship between the knowledge of traders on the measures to prevent COVID-19 disease in the Kotabatu Warkuk South Ranau market. It is hoped that traders at the Kotabatu Warkuk South Ranau market will continue to carry out prevention efforts by implementing health protocols to prevent the spread of COVID-19.
\end{abstract}

Keywords: Knowledge, Prevention, COVID-19 
CENDEKIA MEDIKA

P-ISSN: 2503-1392

E-ISSN: 2620-5424

\section{PENDAHULUAN}

Coronavirus Disease 2019 (COVID19)merupakan penyakit akibat virus corona jenis baru yang muncul pada akhir tahun 2019 pertama kali di wuhan, china yang saat ini menyebabkan pandemi hampir diseluruh dunia. Gejala utama penyakit COVID-19 yaitu batuk, demam, dan sesak napas. COVID-19 merupakan keluarga besar yang ditularkan secara zoonosis (antara hewan dan manusia) dan dapat menyebabkan gejala ringan hingga berat. Sebelumnya, setidaknya terdapat dua jenis corona virus yang diketahui menyebabkan penyakit pada manusia yaitu Middle East Respiratory Syndrome (MERS-CoV) dan Severe Acute Respiratory Syndrome (SARS-CoV).

Data World Health Organization (WHO) dalam Kemenkes tahun 2020, Angka kejadian kematian akibat COVID-19 di dunia tanggal 8 mei 2020 mencapai 3.679.499 orang. Angka kematian 254.199 orang di 215 negara. Sementara di Indonesia angka kejadiannya mencapai 12.776 orang dengan angka kematian mencapai 930 orang.

Jumlah kasus konfirmasi COVID-19 di Indonesia Jumlah kasus meninggal dengan konfirmasi COVID-19 di Indonesia sebanyak 9.448 kasus (CFR 3,93\%). Kasus meninggal hari ini lebih sedikit dibandingkan hari sebelumnya (114 kasus), namun angka kematian ini mengalami penurunan dibandingkan angka kematian satu minggu sebelumnya $(4,03 \%)$. hingga hari ini sebanyak 107.863 orang, jumlah ini bertambah dibandingkan jumlah suspek pada hari sebelumnya (104.866 orang) ${ }^{1}$.

Data Kemenkes RI Tahun 2020, mencatat Provinsi Sumatera Selatan menempati posisi keempat sebagai provinsi dengan tingkat kematian akibat COVID-19 tertinggi di Indonesia. Tingkat kematian akibat COVID19 di Sum-Sel yakni 5,9 persen atau lebih tinggi dibanding angka kematian nasional sebesar 4,1 persen. Dari total konfirmasi di
Sumsel sebanyak 4.675 kasus, angka kematian akibat infeksi COVID-19 berjumlah 278 kasus. Pada tahun 2020 warga Sumatera Selatan positif terinfeksi wabah COVID-19 kembali bertambah menjadi 693 kasus. Di antara pasien baru terkonfirmasi positif, satu berasal dari wilayah baru yakni Kabupaten OKU Selatan. Kasus pertama di OKU Selatan merupakan kasus 689 yakni perempuan usia 62 tahun yang telah meninggal dunia dalam perawatan di Lampung sebelum dinyatakan positif COVID-19.

Tanda dan gejala infeksi pada penderita COVID-19 yaitu batuk, demam, letih, sesak nafas, dan tidak nafsu makan. Tanda dan gejala ini beda dengan infeksi pada virus influenza, virus corona dapat berkembang biak secara cepat sehingga menyebabkan penderita mengalami keparahan, gagal organ sampai kematian. Keadaan darurat Kesehatan ini terjadi pada pasien yang memiliki Riwayat penyakit sebelumnya atau komorbid $^{2}$. Saat ini belum ada vaksin atau terapi antivirus khusus untuk infeksi SARSCoV2. Penatalaksanaan didasarkan pada tindakan pencegahan dan pengobatan gejala orang yang terinfeksi ${ }^{3}$.

Penularan COVID-19 terjadi melalui droplet yang mengandung virus SARSCoV2 yang masuk ke dalam tubuh melalui hidung, mulut dan mata, untuk itu pencegahan penularan COVID-19 pada individu dilakukan dengan beberapa tindakan yaitu membersihkan tangan secara teratur, menggunakan alat pelindung diri berupa amsker, menjaga jarak minimal 1 meter, membatasi diri terhadap interaksi/ kontak dengan orang lain, saat tiba dirumah setelah berpergian, segera mandi dan berganti pakaian, meningkatkan daya tahan tubuh, mengelola penyakit penyerta, mengelaola kesehatan jiwa dan psikososial, apabila sakit menerapkan etika batuk dan bersin, dan menerapkan adaptasi kebiasaan baru ${ }^{4}$.

Pasar merupakan pertemuan dan penawaran dalam proses, ruang dan waktu ${ }^{9}$. Pasar 
CENDEKIA MEDIKA

P-ISSN: 2503-1392

E-ISSN: 2620-5424

tradisional menjadi salah satu klaster penyebaran Covid-19 di sejumlah daerah dikarenakan banyaknya pedagang pasar tradisional yang terjangkit virus Covid-19. Pasar tradisional merupakan kategori tempat yang rentan menjadi lokasi penularan karena kondisi pasar sebagai fasilitas umum tempat terjadinya jual beli kebutuhan sehari-hari dan banyak orang beraktivitas di lokasi tersebut yang datang dari berbagai tempat yang menjadikan pasar seringkali penuh dan sesak dimana social dan physical distancing sulit diterapkan. Kebersihan yang kurang terjaga, dan standar sanitasi dan higienis yang belum ketat, membuat pasar menjadi tempat yang berisiko tinggi untuk penyebaran penularan Covid-19. Ditambah lagi para pedagang pasar maupun pembeli masih banyak yang tidak menggunakan masker dan tidak mengikuti protokol kesehatan yang sudah ditetapkan pemerintah (Girsang, V. I., Harianja, E. S., dan Purba, I. E., 2020). Dengan adanya uraian di atas maka peneliti ingin meneliti tentang pengetahuan pedagang terhadap tindakan upaya pencegahan penyakit COVID-19 dipasar Kotabatu Warkuk Ranau Selatan.

\section{METODE}

Jenis penelitian ini adalah menggunakan desain cross sectional. Dalam penelitian ini Variabel Independen adalah Pengetahuan dan Variabel dependen adalah Tindakan Upaya Pencegahan. Pengumpulan data menggunakan kuesioner dengan pertanyaan tertutup.

Adapun populasi dalam penelitian ini tidak diketahui sehingga pengalihan sampling dengan metode accidental sampling di wilayah Warkuk Ranau Selatan periode April - Juli Tahun 2021. Apabila populasinya tidak diketahui secara pasti jumlahnya, maka tekhnik yang digunakan paling sedikit harus empat atau lima kali dari jumlah item pertanyaan. Dalam penelitian ini terdapat 20 item pertanyaan. Jadi jumlah sampel yang diambil dalam penelitian ini adalah 100 sampel (20 item pertanyaan x 5).

\section{HASIL}

\section{Pengetahuan}

Tabel 1.

\section{Distribusi Frekuensi Pengetahuan}

\begin{tabular}{lcc}
\hline \multicolumn{1}{c}{ Pengetahuan } & Jumlah & Persentase \\
\hline Baik & 82 & $82 \%$ \\
Kurang Baik & 18 & $18 \%$ \\
\hline \multicolumn{1}{c}{ Total } & 100 & $100 \%$ \\
\hline
\end{tabular}

Tabel 1 menunjukkan Pengetahuan Pedagang dengan kategori baik sebanyak 82 orang $(82 \%)$.

\section{Tindakan Upaya Pencegahan}

Tabel 2.

Distribusi Frekuensi Tindakan Upaya Pencegahan

\begin{tabular}{|c|c|c|}
\hline Tindakan Upaya Pencegahan & Jumlah & Persentase \\
\hline Baik & 60 & $60 \%$ \\
\hline Kurang Baik & 40 & $40 \%$ \\
\hline Total & 100 & $100 \%$ \\
\hline
\end{tabular}


Tabel 2 menunjukkan Tindakan Upaya dengan kategori baik sebanyak 60 orang Pencegahan yang dilakukan oleh Pedagang (60\%).

Pengetahuan Terhadap Tindakan Upaya Pencegahan

Tabel 3

Pengetahuan Terhadap Tindakan Upaya Pencegahan

\begin{tabular}{|c|c|c|c|c|c|c|c|}
\hline \multirow{3}{*}{ Pengetahuan } & \multicolumn{4}{|c|}{ Pencegahan } & \multirow{3}{*}{ Jumlah } & \multirow{3}{*}{$\%$} & \multirow{3}{*}{ p value } \\
\hline & \multicolumn{2}{|c|}{ Baik } & \multicolumn{2}{|c|}{ Kurang Baik } & & & \\
\hline & $\mathbf{N}$ & $\%$ & $\mathbf{N}$ & $\%$ & & & \\
\hline Baik & 54 & 54 & 28 & 28 & 82 & 82 & \\
\hline Kurang baik & 6 & 6 & 12 & 12 & 18 & 18 & 0,022 \\
\hline Total & 60 & 60 & 40 & 40 & 100 & 100 & \\
\hline
\end{tabular}

Tabel 3 menunjukkan bahwa pedagang yang memiliki pengetahuan baik dalam melaksanakan tindakan upaya pencegahan sebanyak 54 orang (54\%), pengetahuan baik tetapi dalam tindakan upaya pencegahan kurang baik sebanyak 28 orang (28\%). Dari hasil uji statistik didapatkan bahwa terdapat hubungan yang bermakna antara pengetahuan pedagang terhadap tindakan upaya pencegahan penyakit COVID-19 dipasar Kotabatu Warkuk Ranau Selatan ( $p$ value $=0.022$ ).

\section{PEMBAHASAN}

Hasil penelitian terdiri dari statistika deskriptif didapatkan dari hasil penelitian variable pengetahuan dengan kategori baik sebanyak $82 \%$. Hasil dari variable tindakan upaya pencegahan dengan kategori baik sebanyak $60 \%$.

Hasil penelitian analisa Bivariat menggunakan metode desain cross sectional, didapatkan terdapat hubungna yang bermakna antara pengetahuan pedagang terhadap tindakan upaya pencegahan penyakit COVID-19 dipasar Kotabatu Warkuk Ranau Selatan ( $p$ value $=0.022$ ).

Peningkatan pengetahuan menurut Green (1991), mempunyai hubungan yang positif denga perubahan perilaku. Pengetahuan dapat diperoleh dari tingkat pendidikan karena semakin tinggi pendidikan seseorang maka makin realitas cara berfikir seperti semakin luas ruang lingkup jangkauan berfikirnya ${ }^{10}$.

Tindakan upaya pencegahan COVID-19 yaitu membersihkan tangan secara teratur, menggunakan alat pelindung diri berupa amsker, menjaga jarak minimal 1 meter, membatasi diri terhadap interaksi/kontak dengan orang lain, saat tiba dirumah setelah berpergian, segera mandi dan berganti pakaian, meningkatkan daya tahan tubuh, mengelola penyakit penyerta, mengelaola kesehatan jiwa dan psikososial, apabila sakit menerapkan etika batuk dan bersin, dan menerapkan adaptasi kebiasaan baru ${ }^{4}$.

Pedagang pasar merupakan kelompok yang paling berisiko tertular Covid-19. Hal tersebut dikarenakan pedagang pasar berinteraksi intens dengan banyak orang tanpa mengetahui apakah pembeli tersebut membawa virus Covid-19 atau tidak. Penggunaan masker di kalangan pasar adalah hal yang mutlak untuk pencegahan Covid-19. Mereka juga seharusnya mengganti masker yang mereka gunakan minimal per 4 jam. Sehiggapedagang pasar sebaiknya membawa masker cadangan saat mereka berangkat dari rumah. Pengetahuan mengenai masuknya virus ke dalam tubuh melalui saluran pernafasan sertakeluarnya virus dari dalam tubuh melalui saluran pernafasan dan mulut perlu ditekankan dengan harapan mereka akan mengerti pentingnya penggunaan masker ${ }^{5}$. 
CENDEKIA MEDIKA

P-ISSN: 2503-1392

E-ISSN: 2620-5424

Penelitian ini sejalan dengan hasil penelitian yang dilakukan oleh Moudy, J. dan Syakurah, R. A. (2020) didapatkan terdapat hubungan yang bermakna antara pengetahuan terhadap tindakan upaya pencegahan COVID-19 dengan nilai $p$ value $=0,000^{6}$. Penelitian yang dilakukan oleh Suryaningrum, F.N. (2020) didapatkan hasil terdapat hubungan yang bermakna antara variabel pengetahuan dengan upaya pencegahan COVID-19 dengan nilai $p$ value $=0,000^{7}$.Penelitian yang dilakukan oleh Mujiburrahman, Riyadi, M. E., dan Ningsih, M. U. (2020) didapatkan hasil ada hubungan yang bermakna antara pengetahuan dengan perilaku pencegahan COVID-19 dengan $p$ value $=0,001^{8}$.

\section{KESIMPULAN}

Pengetahuan masyarakat akan upaya pencegahan terhadap penularan COVID-19 dipengaruhi beberapa hal diantaranya kesadaran sendiri akan kesehatan masingmasing. Semakin tinggi tingkat pengetahuan seseorang jika dalam tindakan upaya pencegahan rendah maka akan mempengaruhi tingkat penularan COVID-19 dilingkungan pasar.

\section{SARAN}

Masyarakat yang bekerja dipasar sebagai pedang yang menjadikan keharusan untuk mencari rezeki secara langsung bertemu dengan konsumen/ pembeli, tidak menutup kemungkinan mereka akan lalai ataupun belum terbiasanya dengan dalam menerapkan kebiasaan baru dalam tindakan upaya pencegahan terhadap penyebaran COVID-19. Dalam menjaga kondisi kesehatan saat ini diwajibkan untuk pedangan senantiasa untuk tetap selalu menerapkan tindakan upaya pencegahan COVID-19, bukan hanya untuk diri sendiri namun untuk keluarga agar terhindar dari COVID-19.

\section{DAFTAR PUSTAKA}

1. Keputusan Menteri Kesehatan Republik Indonesia Nomor HK.01.07/MENKES/413/2020 Tentang Pedoman Pencegahan Dan Pengendalian Coronavirus Disease 2019 (COVID-19). https://covid19.go.id/storage/app/media/ Regulasi/KMK\%20No.\%20HK.01.07M ENKES-

4132020\%20ttg\%20Pedoman\%20Pence gahan\%20dan\%20Pengendalian\%20CO VID19.pdf

2. Mona, N. (2020). Konsep Isolasi Dalam Jaringan Sosial Untuk Meminimalisasi Efek Contagious (Kasus Penyebaran Virus Corona Di Indonesia). Jurnal Sosial Humaniora Terapan, 2(2), 117125.

3. Azer, S. A. (2020). COVID-19: Pathophysiology, diagnosis, complications and Investigational therapeutics. New Microbes and New Infections, 100738.

4. Sugihantono, A., dkk.(2020). Pedoman Pencegahan Dan Pengendalian Coronavirus Disease (COVID-19). Jakarta: Kementerian Kesehatan RI

5. Girsang, V. I., Harianja, E. S., dan Purba, I. E. (2020). Pencegahan COVID19 Pada Pedagang Pasar Karya Wisata Kelurahan Gedung Johor. http://ejournal.sari-

mutiara.ac.id/index.php/JAM/article/vie w/1519

6. Moudy, J., \& Syakurah, R. A. (2020). Pengetahuan Terkait Usaha Pencegahan Corona Virus Disease (COVID-19) di Indonesia.

http://journal.unnes.ac.id/sju/index.php/ higeia, 333/345.

7. Suryaningrum, F.N. (2020). Hubungan Pengetahuan Dan Persepsi Masyarakat Dengan Upaya Pencegahan Covid-19 Di Kelurahan Srondol Wetan, Semarang. http://eprints.undip.ac.id/81710/ 


\section{P-ISSN: 2503-1392}

E-ISSN: 2620-5424

8. Mujiburrahman, Riyadi, M. E., dan Ningsih, M. U. (2020). Pengetahuan Berhubungan Dengan Peningkatan Perilaku Pencegahan COVID-19 Di Masyarakat. http://ejournal.polnustar.ac.id/jis/article/view/38 $7 / 276$

9. Damsar dan Indrayani. (2018). Pengantar Sosiologi Pasar. Jakarta: Prenademedia Group.

10. Green, Lawrence W., \& Kreuter, Marshall W. (1991). Health Promotion PlanningAn Educational and Environmental Approach. London: Toronto-MayfieldPublishing Company. 